笔達し，進田してきたてとであり，Table 3 で見られ

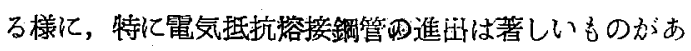
る・また継目無鋼管製造設㣁において，小鋼皃からの製 造方法が，次第䎲姿を消したてと，接合鋼管製造設请に

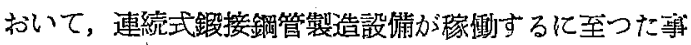
も，大きな变化の一つと思われる．とれら庄延設供の進 路と共に，仕上加工設请にわいてもまた，加工能率の上

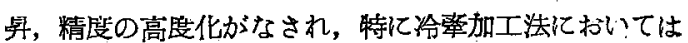
全く一新されてきたというととができる.

$$
\text { 交献 }
$$

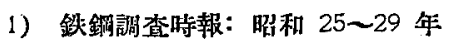

2）鉄錒生産設䚚能力周：日本鉄銅連盟， 昭和 28 年度肘

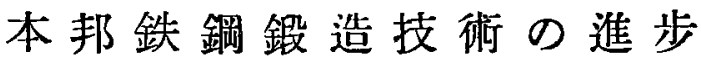

\author{
小林 佐 三 郎*

\section{DEVELOPMENT OF STEEL FORGING PROCESS IN JAPAN} \\ Sasaburo Kobayashi
}

\section{Synopsis:}

The steel forging industry in Japan, which had suffered a tragic outcome due to downfall of heavy industries after the Great War- 1 , gradually has been recovering with rehabilitation. of industries. Nevertheless, from the perspective of quantity, the 1953 figure. still lies at the stage of $38 \%$ of the 1940 statistics. In the field of techniques, however, rationalization of the equipment has proceeded and attained to an international level in many points owing to introduction of the heat control, the metallurgical control and the statistical quality control. The present paper described the progress in the modern forging tèchnique with. reference to heavy rotorshafts for generators, steam-turbine rotorshafts and others. The heat treatment after forging of these forged products has made so much progress and, by utilization of the S-curves, forgings have been less liable to suffer from occurrence of flakes. Also, the inspection of internal defects in these forged products by use of supersonic waves has been applied in practice, especially to the generator-rotorshafts.
\end{abstract}

\section{I. まえがき}

第二次世界大戦後の我国重工業の立直りは施設の復

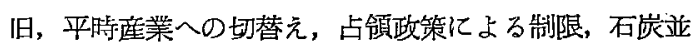
びに電力等情の湢迫等，諸票爱の影響によつて容易では なかつたが，哉中，他座業の需要に応じて消長する鍛鋼 業の沈滞の状洗は，真に深刻であつた。

戦時中，急速に堌强を見た中小企業の所謂鉔工品工業

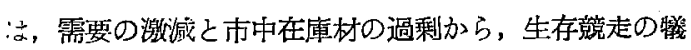
牲となるものが多く，大企業の大型践造施設も辛うして 操業を續ける有様であつた。

やがて昭和 25 年頃から，鉄銅業および造船業の著し い復興に次いで, 電源開発に伴う雷機業と, 化学工業,

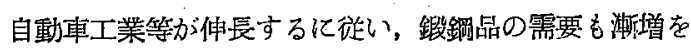
来し, 昭和 28 年度には, 約 $110,200 \mathrm{t}$ を生産しやや好況 を呈したが，とれとても昭和 15 年度の $38 \%$, 終戦時の
61\%に過きぬ状態であつた.

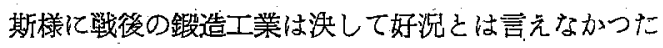
が，反面技術上，作業上の仕事は多等であつたのであつ て，また渺からず進歩もしたのである．即ち民需品への 耺換，或いは新製品の開拓に際しては，藷しく進歩して いた外国の水㲚に到達するために，製造法の研究と品質 の改善に努力し，また経済性を確保するために設请の合 理化, 熱管理, 冾金管理, 品質管理等を行い来つたので ある・

以下に，水圧プレスによる大型銅材の銠造に関して，

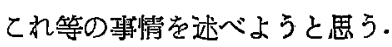

\section{II. 加 熱 法}

鋼材の加蓺温度は，加工温度籍国を広くするために，

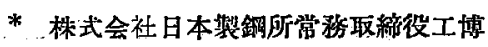


Table 1. Production of forgings in Japan.

unit:metric ton

\begin{tabular}{|c|c|c|c|c|c|c|c|c|}
\hline Specification & 1926 & 1930 & 1935 & 1940 & - 1944 & 1945 & 1946 & 1947 \\
\hline $\begin{array}{l}\text { Plain steel } \\
\text { Special steel } \\
\text { Total }\end{array}$ & $\begin{array}{l}24,353 \mathrm{t} \\
24,253\end{array}$ & $\begin{array}{l}26,895 \\
26,895\end{array}$ & $\begin{array}{c}72,030 \\
72,030\end{array}$ & $\begin{array}{l}171,936 \\
124,982 \\
296,918\end{array}$ & $\begin{array}{l}188,026 \\
315,445 \\
503,471\end{array}$ & $\begin{array}{r}68,013 \\
116,244 \\
184,257\end{array}$ & $\begin{array}{r}19,247 \\
7,473 \\
26,720\end{array}$ & $\begin{array}{r}22,564 \\
8,353 \\
30,917\end{array}$ \\
\hline $\begin{array}{l}\text { Fiscal year } \\
\text { Specification }\end{array}$ & 1948 & 1949 & 1950 & 1951 & 1942 & 1953 & \multicolumn{2}{|c|}{$\begin{array}{l}1954 \\
\text { first-half) }\end{array}$} \\
\hline $\begin{array}{l}\text { Plain steel } \\
\text { Special steel } \\
\text { Total }\end{array}$ & $\begin{array}{l}34,665 \\
11,510 \\
46,175\end{array}$ & $\begin{array}{l}48,660 \\
13,353 \\
62,013\end{array}$ & $\begin{array}{l}60,330 \\
15,990 \\
76,320\end{array}$ & $\begin{array}{l}72,985 \\
20,119 \\
93,104\end{array}$ & $\begin{array}{l}61,202 \\
25,134 \\
86,336\end{array}$ & $\begin{array}{r}80,255 \\
31,974 \\
112,229\end{array}$ & \multicolumn{2}{|c|}{$\begin{array}{l}35,955^{\cdots} \\
14.423 \\
50,378\end{array}$} \\
\hline
\end{tabular}

鉶材の劣化，或いは廃却にまでおよぶ過熱または然烧を 生じない限りの最高温度が選ばれる.R.M. Keeney 等 は，乙の温度は各種鋼材の固相線下 $80^{\circ} \mathrm{C}$ が適当である としている・しかし温应が高過ぎると，然料の焚狫方式 等の笑䟢面から過熱，然烍の危険が充分ある・鉄鋼協会 では，同会編纂の「鋼の熱処理と作業標準」の中で, 加 熱湜度につき論し，大鍓塊を使用し，比較的仕上代を多 く附して，表面の不良部分の除去を多く見込み得るもの に対しては，一般に Keeney の最高加熱温度を採用す るが，仕上代か僅少なことを要する小物に対しては，各

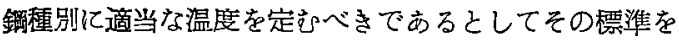
示している.

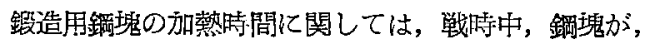

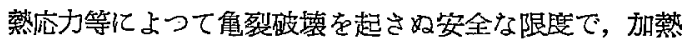
時間を短縮する事を主眼として，加熱㭙間の標準化が企 図された事があつた。筆者等は，その理諭的根拠として G. Stanfield の算式を採用し，てれに若下の現場的修 正を施して標準加熱時間を定めた。

$$
\begin{aligned}
& \frac{\mathrm{d}^{2}}{169}+\frac{\mathrm{d}}{8}+\frac{\mathrm{d}^{2}}{285}=\mathrm{D} \text { (時間) } \\
& \mathrm{d}: \text { 銅塊の直径 (时) }
\end{aligned}
$$

第 1 項 常温より $550^{\circ} \mathrm{C}$ までの加蓺時間

第2 項 $550^{\circ} \mathrm{C}$ より $1200^{\circ} \mathrm{C}$ まて加蓺時間

第3 項 $1200^{\circ} \mathrm{C}$ に保持する時間

鉄鋼協会の特珠鋼標準熱処理研究会では，加熱時間に 関する各説を吟味し，本式より湲いた時間も標準として 信頼しうるものとした.

戦後，鋼材の方熱沠に関し特記すべき事柄は，昭和24 年来日した米国技師 F. N. Hays 氏等によつて熱管理 の重要性が强調され，その指導を受けて操炉法の玫善, 設倩の政良，更新が行われたととである。

昭和 24 年には，熱経济技術部会が設监され，熱管理 誠査団を組幽して，各会社の熱管理上の䛦断と指導を行
う等，全国に亘つて䓡経済への関心と活動が高まつたの である。

Hays 氏の主張する平师における push-pull の原則 による所謂正圧操炝法は，銀造用加蓺炉にも当然適用さ れる所であつて，例を発生师ガス焚烧の大型ハッチ加熱 炬に採れば，自然通風を改めて送風機による强制送風と し,煙道ダンバーの制御を厳にし，炉内雾団気を正圧とし て外気の侵入を防ぎままだスと空気とを混合貲王する 様に開口改めて完全然焼园る等，然焼方法の改善が 行われた. 一方熱効率の向上を図るために，加熱㠼の熱 損失の㭘討が行われ，断熱䑁瓦を以て妒体の放熱を防ぎ 或いは排ガスる利用して，余熱ボイラーを稼働すること 等が行わ机た. Fig. 1 はこれ等一連の焼䉓理刘策を取. 入れた加蓺設備の一例を示す。

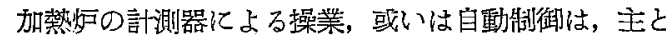
して均熱戸，連続加熱师等におかいて行われているが，大

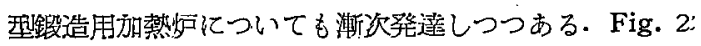
の例では，炉内天并温这，ガスおよび空気蓄熱窒温度， 煙道温度の計測器と送風在, 炉内圧, 排ガス代の测定器 およご炉内炭酸ガ ス率の測定器を倩えて, 笑續の記録か ら作業標準をたてて操業する.

熱経済と関連し，高炭佂の影響から，然料として重油が. 石炭に代つて使用されるに至つた班は著しい傾向と言え

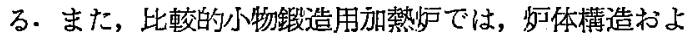
び加熱形式の特珠なものとして，回枟式加答炉（Rotary furnace) が我国にも流布されるに至つたが,熱效率: は假秀で,多量生産加熱炉として期待されるものであるー

\section{III. 鍛 造 用 鋼 塊}

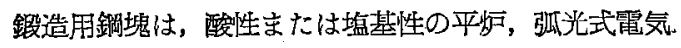
炉および高周波電気炉製の鋼によつて作られるが，何れ も充分に眖酸した優良なものでなければならない，重要

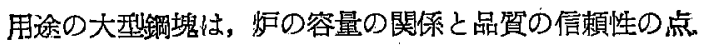




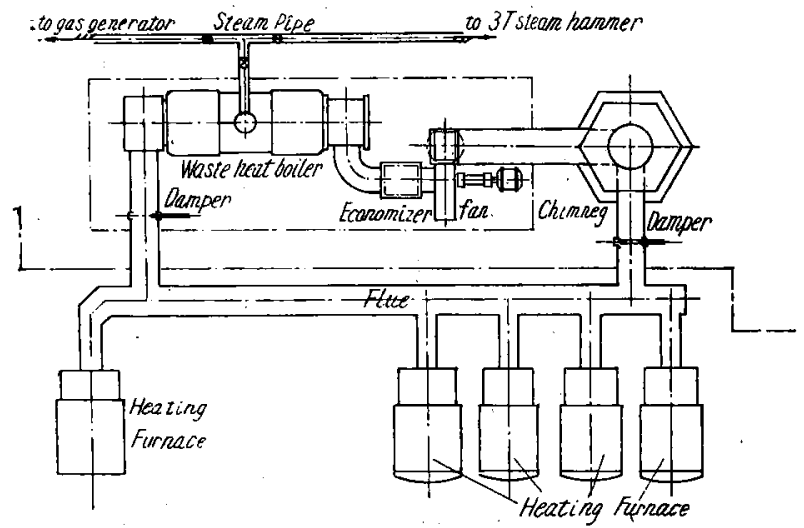

Steam boiler type capacity Max-press Waste gas temp.

Stationary. horizontal fire-tube $1 \cdot 5 \sim 2 \mathrm{t} / \mathrm{hr}$ $8.5 \mathrm{~kg} / \mathrm{cm}^{2}$ inlet $250 \sim 300^{\circ} \mathrm{C}$ outlet $180 \sim 200^{\circ} \mathrm{C}$

Heating furnace:

Composition of waste gas $\mathrm{CO}_{2} 16 \cdot 5 \% \mathrm{O}_{2} 1 \%$ Thermal efficiency $18 \cdot 5 \%$

Fig. 1 Layout of heating furnaces and a waste heat boiler.

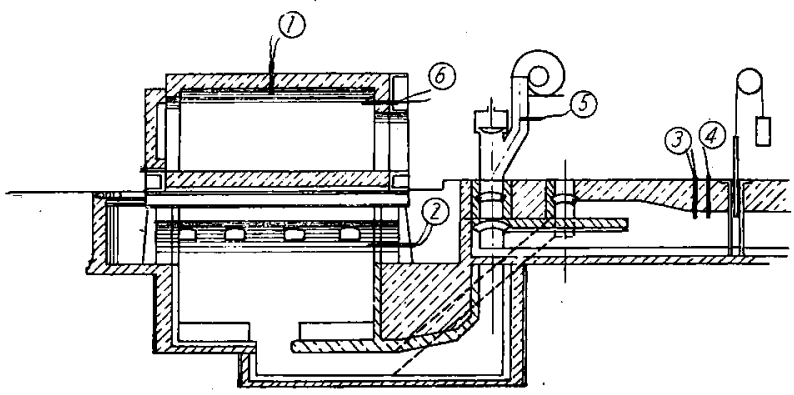

1. Pyrometer for furnace 4. Draftmeter for flue

2. Pyrometer for heat chamber 5. Air flowmeter

3. Pyrometer for flue

6. $\mathrm{CO}_{2}$ meter

Fig. 2 Arrangement of measuring instruments for heating furnace:

から, 酸性平炉鋼が学用されるが, 貸源の少い我国で, 低燐，低硫黄銑等の制約のない安価な塩基性平师鋼を用 いる研究力戦前汃行われてきた。 しかし，塩基性平少

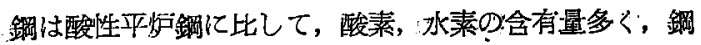
塊内部の気泡性地疪が生じ易く, 萃面疪も多い票は事実 てであるので，重要品，特殊鋼製品に使用する事は，末だ 警戒を要するところである。

鋼塊の表面疪，収縮孔(組織の粗箖，所謂ザク含め) 偏折, 気泡, 白点, 粒界龟裂, 秒疪, 非金属介在物等の
欠陷の内，製鋼上，銀造上の因難なものの尤 なるものは収縮孔及び杪疪である。収縮孔は

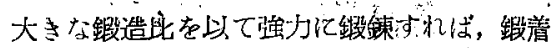
せられるものであるが，應々改盖し得程に 雷大な場合がある.

造施技術の領域化属するが，収縮孔仗，直 径の大きい(高さと直径の比 $1 \cdot 5 \sim 2 \cdot 0$ ) 傾 斜の強い，厚肉の下方に厚い鋳型を淢いて，

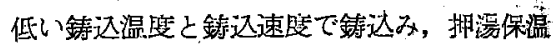
を行う等により防止するが，この鋳达法注杪 疪の防止法と矛盾するので，'その洋ね合は造 闍上の重点となる。

近時，超音波探傷法，或いはケイントーダ によつて，鋼材の内部矢宿の判定が行われる

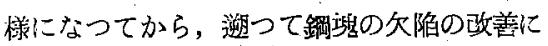

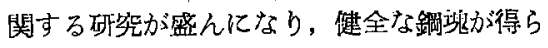
れつつある筙は喜ばしいことであう。

\section{IV. 鍛造プレス及び附帯設備}

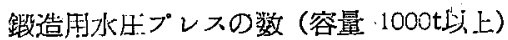
は，戦㭙中念激に膨脹して，80数合を数えて いたが，戦後激淢して，今日稼衝しているの は約 30 台に過ぎない。

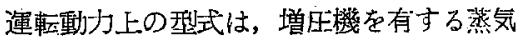
水圧式と空気蓄勢機を有する純水日式のみ （殆んど同数）であつて，構造 ま，浪本的に 新規な点は認められない。

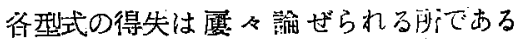
か，戦後は，石炭，電力の害情から，地域的制

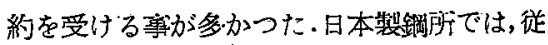
来の蒸気水玨式を廃して，純水殴式，2000tプ レスを 10000t プレス工堷に移設し，長い水

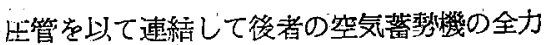
を利用する害化より，作業費の節娍を四つて 効舆を举げており，更に 1000 フプレスも同 様移設する予定である.

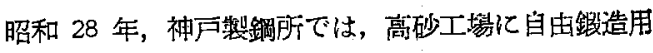

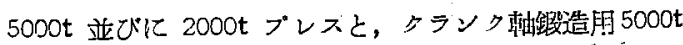

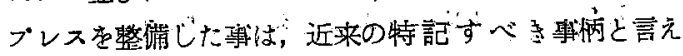
る.

附带設䚛として，材料操作用機械は，専ら鏗造迟雷機 （ターニンダギヤー安用う）加用いられていらが，欧米 では遥かに能率的な䤪造用マニブレーダーが使用されつ つある状海から，我国でも錪造施設合理化の一環として 
その採国が希望され，昭和 29 年初め，独乙から容量

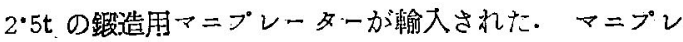
一ターの利点は材粼を堅固に把持し動作が確実迅速で,

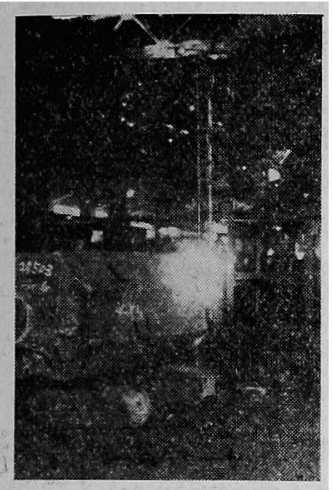

Fig. 3. Gas cutting of sink-head of a $25 \mathrm{t}$ ingot.
かつ人力を要しない等にあ

り，鉔造作業に專往し得る

ので生産量は 3.5 倍にも增 大すると言われる：近く国 産も可能であるから我国鉔

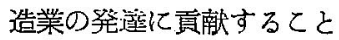
であらう。

近時，酸素〉七チレン瓦 斯による余材の切断, 圾験 片の切断，或いは堸堄およ び鋼矿の疪取りが盛んにな り，ガス划断設橵が錳造工 埸に必要欠くべからざるも のとなつた等は特記すべき

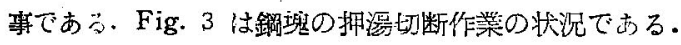

\section{V. 鑹 造 法}

銀造の目的流，鋼嵲を所要の班状に成形し粗大な錆造 組緎を欧善し，材力る问上させるにある武は言うまでも ない.

内部組織を欧善するには，金教の门を大きくし，接触

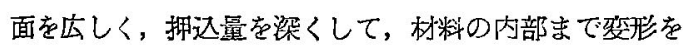
与える事である.粘土笑鈳によれば金敷の川は材料の直 径の 40\% 以上，拥远量 $7 \%$ 以上である㔜方有効であ

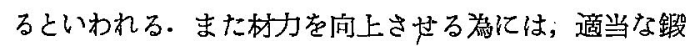
造比を上て锞造する事を要する.銀造比と内部組織の变 化礼よび材力との関倸は, 徉来多くの研究が行われてお り結論は略々一致している・即ち䄪力について言えば,跛

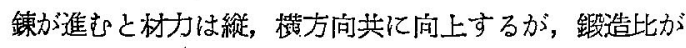
3 より增加すると荟方向の伸び，絞り，衝慗值力゙低下し て行く，よつて，例えば発電機回転子檕， クランク軸等 棤方向の材力る要求するものに対しては適当な鎦造比 (2・5〜3・0) に止めておく必要がある.

大きな断面積を有する製品仙は，直径の大きな，一般

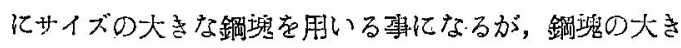
さが增すと，偏折，不紋物，制㣗疪，收縮孔等の不健全 さを增す不利がある.製品に対しては最も小さい鈵塊を

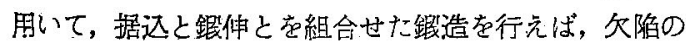
ない㴖足な材力を有する鋼材が得られる.しかし，鋼塊 の内部の欠陷の司る種のもの（例えば収縮孔）は，据込 によつて斯つて满方向に拡大され，繶く鍛伸によつても

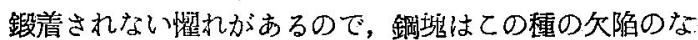

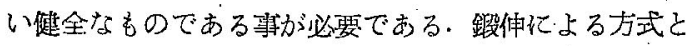
据込と鈠伸の組合せによる力式とに対する見解は，国の

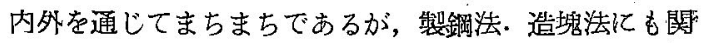
係する巫なので．との選択は製造者の経験に応じて行㕲 れるべきものと䍐う。

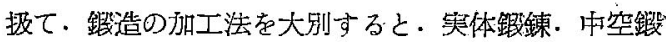

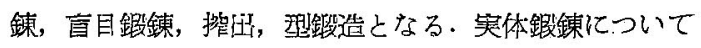

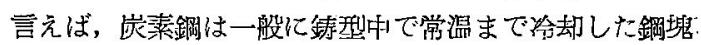
を，要すればテッビング，スカーフィングで予め裁面の 手入を行つてから，適当に篹した上，加熱师で加熱す

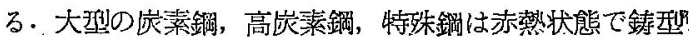

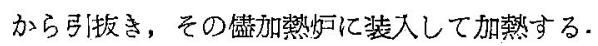

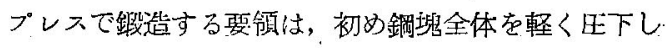

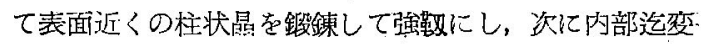
形を与える倳に强く日下する。

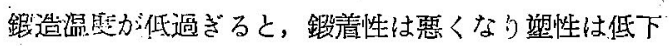

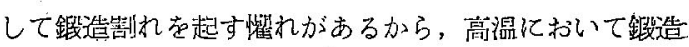
する聚は一般に有利である。また鍇鍊仕上げ寸法近くで

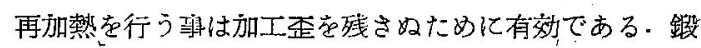
造中表面に笔生した疪はスカーフィングにより警間で除 去しつつ作業を続ける。

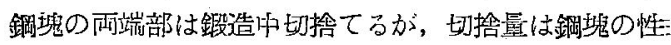
状に応じて適些に選ぶべきで，一船に頂部側は全重量の $25 \%$ (内本体 $5 \%$ ) 底部側は6\%（内本体 $3 \%$ ) 程度で

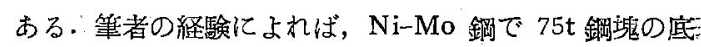
部側は，砂疪方軓生し易いため，本体を約 10\% 切唅て る等とする例がある。

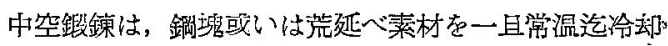
した後，機㭜で賄端を切断し中心に穿孔した上加熱して 心金により銭伸，または孔执げをして成形する・然し現 在では鋼榇をその情方熱し，プレスで両端切断の上据达

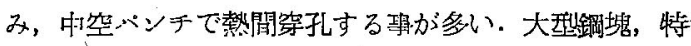

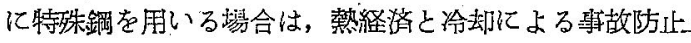
の上から有利である.

亘目銀鍊は，鋼塊の中心の粗悪部を取り除くために，

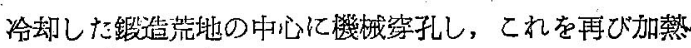
して孔を鉔推する方法であつて，鋩中含有ガスの昖散， 内部応力の緩和に役立つとされ，砲身材，回転子材の鉔 造に利用されたが，琴在では製造法が進些して，本法は 全く行われていない.

䤵造に関する基礎的研究は，望性理諭の伈用に関する

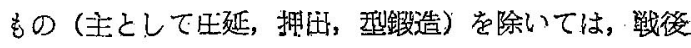
に発表されたものは少い，しかし製造者，使用者間の踪 
造洗に関する研究会，懇談会は活発に行われ，製品の個 ムに関する跳造法は盛んに研究されている。これに関し ては主要品鍛造洗の項で触れる事とする。

䤨鋼品に適用される諸規格, 仕樣の殆んどが, 直接, 間接に国際的検査拹会（例えば船関係）外国技術協会， 或いは外国会社の基準に関連している事は，戦後の特色 であるが，進歩した海外の技術吸収の时期にあつては己 柾を得始呇であろう。

\section{VI. 主要製品鍛造法例}

\section{1. 発䉓機回転子軸}

我国の発電施設は近時著しく搪充されてきたが，発電 機の容量は益々增大し，性能は高くなつたので，回転子

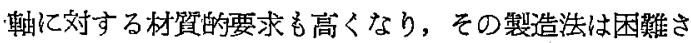
を增してきた．即ち戦前我国で最大とされた2 極3600回 転，30000 kw 級は，今日では $66000 \mathrm{kw}$ 級が標準とな り，回転子軸の重量は增して，使胕する鋼塒う $75 \mathrm{t}$ 或い はそれ以上となつた，健つて鋼材の内部久陷の垷する 恐れが多くなる一方，超音波探傷法の採用によつて湌査

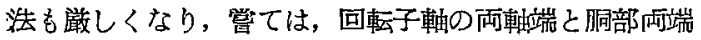
についてのみ行われた材料試験が，管錐法により胴部数 ヶ所, 半径方向の肉厚中央部即ち鋼熄の粗悪部に相当す る部分から採取した試片について行われる事になつたた め, 材力の要求は等案上，菏酭となつた。

回転子軪は，上心に穿孔儿，胴部に菁を切るから内部

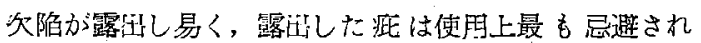
る、鋼塊の性状が健全である事わ问転子㲧製造上の最重 点である事は前記堸塊および銀造泆の項で述べた通りで 古る・鋼種は稀に炭素鋼が用いられるが，一般には Mo 或いはVを単味または同時に添加した $\mathrm{Ni}$ 鋼, $\mathrm{Ni}-\mathrm{Cr}$ 鋼

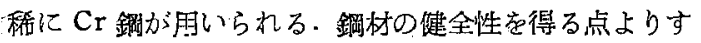
れば，製造上， $\mathrm{Ni}$ 鋼は $\mathrm{Ni}-\mathrm{Cr}$ 鋼より困囉でない経験 を筆者等は持つている. 鉔造は鋼塊を荒延べした後，一 且朝方向に約 $50 \%$ 亿据込み，乙れを再び朝方问に鏗伸

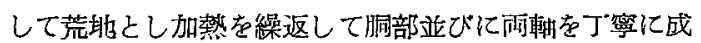
形して什上げる。

超大型の銧塊を使用して，佰部側わよび底部側の粗悪 部を切除して，息貿部のみを国いて据达みを行わずに鐉 造する方法をなす場合があり，特住底部砂疪の回避に は有効な方法で污るが，迢大型による全体の材筫劣化を 恐れて，一般据込み，銀伸の方式が行われる.賞つて

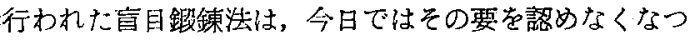

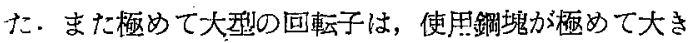
くなり製造上困睢が多小ので, 今日でも, 胴と軸とを分
離して銀造してれを後で結合する．日本製鋼所では，胴 部に 160t 期部に $90 \mathrm{t}$ の鋼塊を使用し, 組立重量 $104 \mathrm{t}$ の回転子軸を製造した。

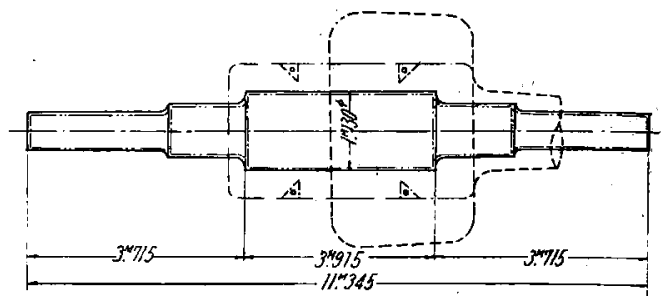

Fig. 4. An example of rotor shaft forging (original ingot $75 t$ )

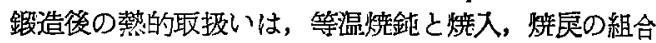
せの方式(後記第 7 項参照)により特に慎更に行われる.

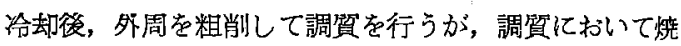
入は要求される機械的强度により，村賀，形状に応じ油 焼入，または焼準が行われる，近時，機械加工，特にス ロットの切削の際や，或いは使团中に変形する事のない 様に焼準を行う事が多く，また指定される轱が多い。

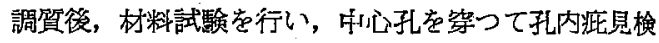
查をし，機械仕上後；要部の硫黄㙋写わよび外部全面仡 亘り超音波探傷を施行して発送する.

戦後，海外における此の方面の進歩恃著しく，て机に 刺䄾されて良品製造に䓀心を重ね，今日では国内で， $100,000 \mathrm{kw}$ 䌅の回転子䩴の製造も左程困難ではなくな つた、てれは官民特に電機製造者の激励協力の晹であ ろ.

2. 蒸気タービン軸审

蒸気タービンも益々甘出力が大きくなり，且つ高温高生 の蒸気が使用される様になつたので軸車の製造も発電機 回転子軸仁劣らず難しくなつた。

材筫，成分は低生軸車に対しては宸素鎆，または Mo

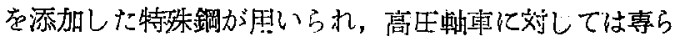
Mo を添加した特殊鋼力゙国いら机る。

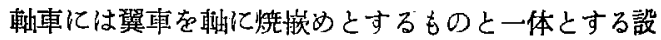

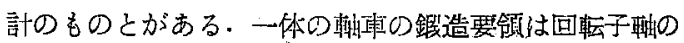

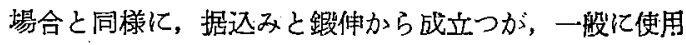
鋼塊に対し製品の直径が大きいので，据込みの量は充分

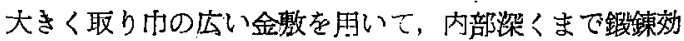

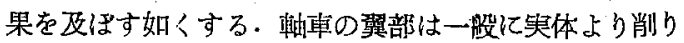

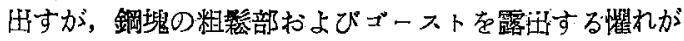
多い故，段落の間隔の大きい場合には，ての部分を背切

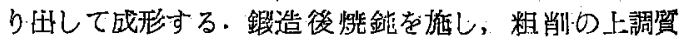
する，熼入は㮱準する場合が多い。 
タービン軸車は前述の通り使用温度が高くなつたので 使用中に高温蒸気に曝されても絶対に歪曲しないと言う 事を確めるために，材料試験および中心孔検查後の素材 代対して，機械加工を終えて最後に，加熱試験が行われ る椂になつた。

加熱試䮖では，訊験前後の軸車の軸しの振れの善が， 0.025 mm 以下である策を以て良とするが，その振れの 過大となる一因が鍜造の不手際にあると言われるので鐉 造仙均等に行う必要がある．Fig. 5 和型入により均等 几成形する例を示した。然しながら桭れを規定内に納め る事は，製造上特異な雪情のない限りは比較的容易であ る事も経臨する陀である。
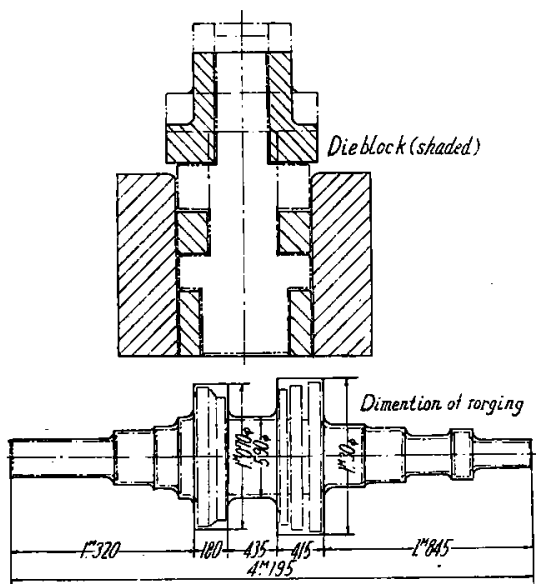

Fig. 5. An example of die-forging of a turbin-rotor.

\section{3. 型 龬}

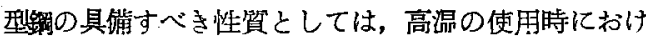

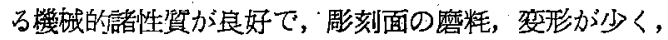
且つ㲘刻の際の被切削性が良好である事と，更にてれ等 の性筫が䍿鋼の内外部において均等であるてとである。

戦時宁，多く使用された所謂代用鋼による聇鋼に対す

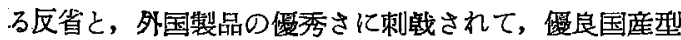
鍓の製造法の䂙究它目的として，昭和 22 年各自動車会 社，製銅所，および研究所を以て組織された型鎆対策委 員会汃発足し，比較目標儿優秀外国製品をわいて，基礎 的，实用的矿究がなされ外国製品に劣ら成筫を得るの も間もないと思われる。

望鎡の鋼種としては， Ni-Cr-Mo 鎦を始めとして，

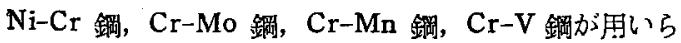
れる．Mo を含む鋼種は，含ま如ものより各種の性資が 良好で，特に Ni-Cr-Mo 鋼が優れている事は既に定言

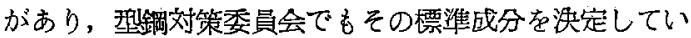
る. Cr-Mo 鋼は高仾な Ni を含まない代替鋼種として 賞用されているが，焙入性の点では含 $\mathrm{Ni}$ 鋼に対しゃゃ 抙色があるので，との点の改善が可究されつつある。

国座 Cr-Mo-V 鋼

$$
\begin{array}{ccccccc}
\mathrm{C} & \mathrm{Si} & \mathrm{Mn} & \mathrm{Ni} & \mathrm{Cr} & \mathrm{Mo} & \mathrm{V} \\
\cdot 25 / \cdot 55 & \cdot 2 / \cdot 35 & \cdot 5 / \cdot 8 & - & 1 \cdot 0 / 1 \cdot 5 & \cdot 35 / \cdot 4 & \cdot 10 \\
\multicolumn{7}{c}{\text { ・ッヘ・ンストール社 }} \\
.5 / \cdot 6 & \cdot 2 / \cdot 3 & \cdot 65 / \cdot 9,5 & \cdot 3 & \cdot 25 / 1 \cdot 15 & \cdot 4 / \cdot 5 & \cdot 06
\end{array}
$$

鋵造法の要点は，鋼材の組蟣の才问性を生ぜしめない

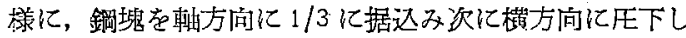
てれを繰返す。

比較的小型の製品に対しては鋼塊を荒延べした後，各 個に切断の上，各面上り据込志所謂六面鉛造苍行う。組

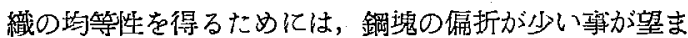
しいので，できる限り単個取りの小型鋼站を使用する。

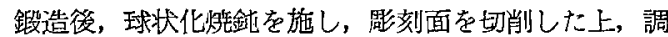
賀する、焼入は油冾または噴油洽却により充分に行う。

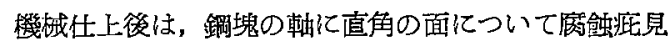
娭查を行い糨に平行な面について超音波探傷試驗を行つ た上玨荷する。

4. クランクアーム

大型ディーゼル船用機関のクランクアームは型が大き 人特異な形状をなしているので，重量の軖减と欠陥防止 の目的で，種々の鉔造法が行われる，戦後，造船計画に 基いて，多量の製品が䤪造され，初期には，実体加ら削 田し，或いはビン部を型入して製造されたが，何れもゴ 一スト，砂疪，ザク疪等が露出して廃却になるるのが多 かつた，各製鋼所では成形洗の研究を重ね，現在では,

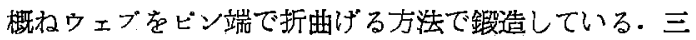
菱長崎㱔銅所では折曲げの優れた鍤造法を洘案した。

\section{5. 一体クランク軸}

一体小型クランク軸は，従来一般に平板に銀浩した荒 地を背切り，この部を喰い下げた上，谷シャ一ナルを機械 加工し，局部加熱して各ジャーナルを㣛る方洗で造られ たが，現在は，工程を簡略するためアームを角磨を与え て錪造する方法が広く行われている。

然し，ピン部は矢張り削り函されるので，材料は不経 淡で，内部欠陷の露琶する曜れがある

仏国の R.R. 法は, 特殊鐉造器具を使用して丸鋼片 支代下しつつ水平方向汇据込み，フームおよびピン部を 形成する考案である.本法は近く，神戸製堸所で笑施さ れ様としている。

6. 回転子エンドリング 
エンドリングは高い機械的强度を要求するので，普通 $\mathrm{Ni}-\mathrm{Cr}-\mathrm{Mo}$ 鋼或いは Cr-Mo 鋼を調䫓して使用するが 最近は発電機の性能を高めるために，高 $\mathrm{Mn}$ 系,高 $\mathrm{Ni}$ Cr 系の非磁鋼党以て製造される様になつた。てれ等鋼 種は熱処理によつては充分な材力を得䧼いので，熱間銀 造徭粗削りした上，若干の冷間銀錬を施して所期の材力 を得る方法を取つている．冷間鈝鍊後，低温烧鈍した材 カの一例を次に示す.

Chemical composition

\begin{tabular}{c|c|c|c|c}
\hline $\mathrm{C} \%$ & $\mathrm{Mn} \%$ & $\mathrm{Cr} \%$ & $\mathrm{Mo} \%$ & $\mathrm{Si} \%$ \\
\hline 0.5 & $18 \cdot 0$ & $5 \cdot 0$ & 0.5 & $0.5 / 0 \cdot 7$ \\
\hline & \multicolumn{1}{c}{ Mechanical properties } \\
\hline \\
\hline $\mathrm{kg} / \mathrm{mm}^{2}$ & $\mathrm{R} / \mathrm{kg} / \mathrm{mm}^{2}$ & $\mathrm{~A}$ & $\mathrm{Ce}$ \\
\hline 85 & 105 & 30 & 50 \\
\hline
\end{tabular}

\section{VII. 鎮鋼材の熱的取扱法}

大型鋼材を鉛造後，常温まで冷却する熱的取报法は最 近 10 年間に可成り進歩した，鐉造後の蓺処理の自的は

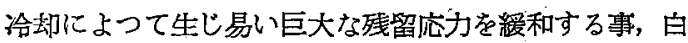
点の発生を防止する慗および粗雑な結晶組織を調整する 事にある.現在一般に行われている熱的取扱法を一括す ると Table 2 の如くなる.

単緍冷却方式は戦前広く用いられた方法で今日では崖 素鋼，或いは低合金鋼のみ利用される。

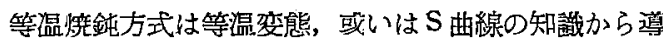
かれ最近広く利用されている方式である.表中， B， C について言元ば，2-4 で結晶粒調整の後，S 曲䠌にお ける $A r_{1}$ 変熊の速度の速い温筑域（鋼種により異るが 一般に $600^{\circ} \mathrm{C} \sim 700^{\circ} \mathrm{C}$ ) 亿保持し，急速に変態を完了せ

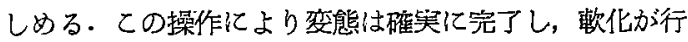
われ，ま执水菜の搪散，白点の防止，残留応力の軽減に 著しい効果か得られる。

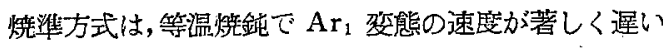
鉡種の場合，操作に莫大な時間を要しかつ不確実となり

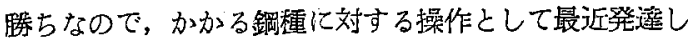
た方式である. 即ち $\mathrm{Ar}_{1}$ の变態によらず， $\mathrm{T}_{8}$ の $\mathrm{Ar}^{\prime}$ 变熊温度域 $\left(250 \sim 400^{\circ} \mathrm{C}\right)$ 亿保持し $\mathrm{Ar}^{\prime}$ 变態を行わし め, 次に $T_{4}$ の变態点下の温度に保持して, 㳄化, 応力

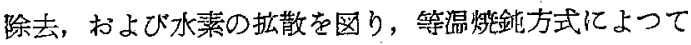

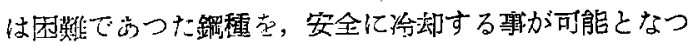
た.
Table. 2.

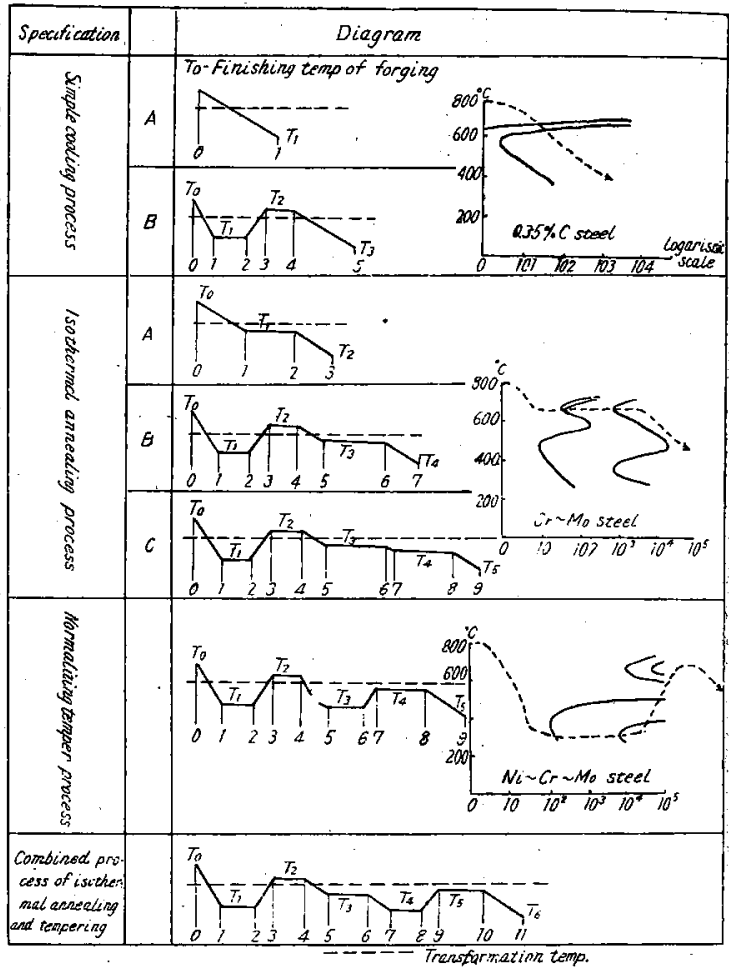

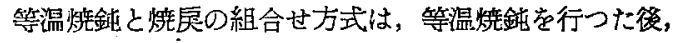
$\mathrm{T}_{4}$ の温唐 $\left(200^{\circ} \mathrm{C} \sim 400^{\circ} \mathrm{C}\right)$ に保持してから $\mathrm{T}_{5}$ の温 度で焼㞔を行う方式である。

要するに最近の熱的取扱洗の特峌は，变熊速度の速い 温度と，水菜拡散速度の最も速い温度（变熊点直下）を 巧に利用したところにある．とれ等の温度と保持時間は $\mathrm{S}$ 曲線より選定し得るが，大型品では，熱伝導,変態熱，!

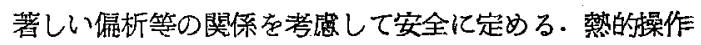
上最終段階の冾却は，各種の割れ疪発生に影鄉する最る 重要な部分であつて，一般には，帅师または小石，砂， 或いは石灰㘯等の中で，極めて緩やか（例兄ば平均速庋 $5^{\circ} \mathrm{C} / \mathrm{h}$ 以下）に冷却する。

\section{XIII. 超音波探傷法}

超音波挬傷法は戦後我国に尊入され，急速に流布され， るに至つた㓻期的品位判定であつて，資量の大きな鋼材 の深部の久樎，および或る種の組織变化を湌查し得るの

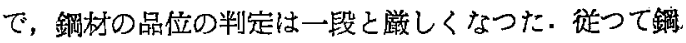
材は本貿的们健全である事が必要となり，制造法は新た な視野から考觉なけれぱならなくなつた。非破塄的に材 
料の欠宿が判定できる事は，探否の早期決定が可能とな り，後続の製造損を救い，或いは材料の粗要部を排して 健全部を利用に供して，事故を未然に防止する事が活来 るのである.事実製鋼所におていては，鋼片或いは調質前 粗削り素材等に対して探賃を行う型を建前とし，特別の 場合には鋼瑰に対してる施行して，安全を期する方洗が 探方机ている。

しかし，本法によつて橹画された久陷の判定が問題で

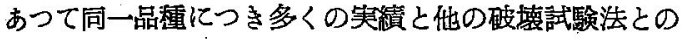
比較等を行う事により初めて可能になるのである，往つ て今日では製品については使用者, 製造者共保位判定 の資料として取上げるに此まり，てれを採否判定の基準 または覞格としたものは少い。

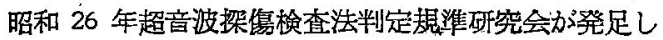

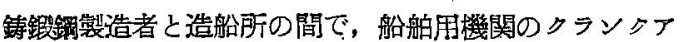
ーム,クロスーッドピン, 中間軸, 推進軸等の判定基淮

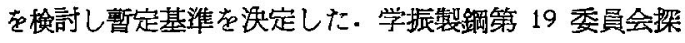

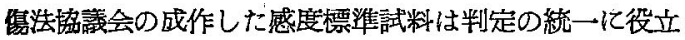
つた.

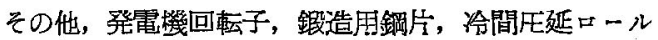
等に対し，或る程度の規格化が，製鋼所と使用者との間 に行われている。然しながら，基集は何れもウ広いもの であつて，判定楛しむ場合にはその都度協議して決定 する方針である重は，拯傷法の性質上，現段階では当然 の事と思われる.

Fig. 6.は発電機回転子の探傷判定例を示す。

\section{IX. 鍜鋼材の欠陥}

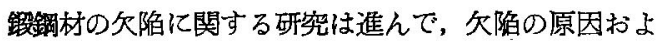
び防止法は漸次明かになりつつあるが，未だ製造上，使 用上の問題となる㲔は多い。

日本鍨鋼会では，銀鋼品の不良品発生を防止する運動 の第一步として，䤵銅㫛の不良原因の呼称の統一と，不 息原因の梁究を企园し，昭和 29 年“不良原因類別 , を制定し，鑂鋼関係者の便に供した。

本項に鉏造上，使用上の問題となる久陷について簡単 に述べる。

気泡： 主として鋼塊の袁面近い（一般に表面より $10 \mathrm{~mm}$ 以内）に生じ，鋼塊激部側，底部側，および隅 角部に氾く存在する．黑皮または仕上代の㒖少な製品に 対しては，鋼塊或いは半作荒地の全表面をスカーフイン グ等により除去する場合がある.

プースト：甚だしく篅厚なもの，或いは龟裂を伴う ちのを除いては，一般に久陷の対象とはならない，閶題
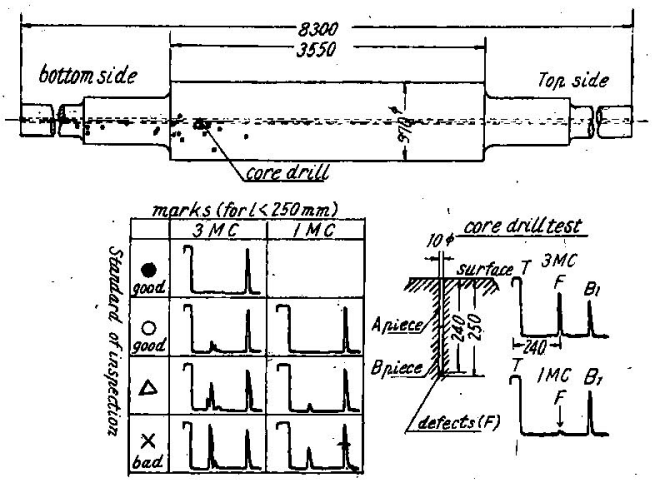

Enlarged figure of $B$ piece

Enlarged figure
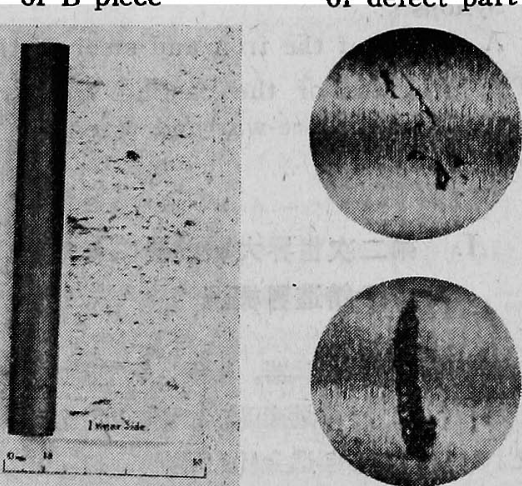

Fig. 6. An example of supersonic inspection of a generator-rotorshaft.

となる場合でも製品に現われた位置によつて可否は考葴 される.ジーストの現われだ材料の探否の一つの基準と して重裂を伴わず，剣バイトによる切削で削り屑の切れ ない程度を以て良とする䄰がある。

ザク疪：鋼塊の中心線に沿うた粗箖部或いは収縮孔 の鉂着されずに残つたものを指す．疪の附近にはガス， 不純物が一般に多いので充分鍛造しない限りは，改善は

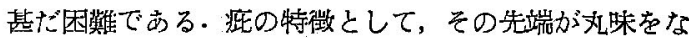
すので，外力に対し大きな応力の集中は起らず重大な害 はなさない様である。

白点：防止法としては，践造においては加熱により

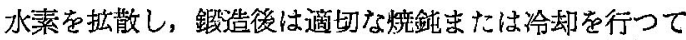
水菜の鋼外放出之抬散を促し，各種応力の生成志抑制卞 る事か湩点として行われる（熱的取㧴法の項参照），今 日，白点に忷まされる事は少くなつている。

\section{X. むすび}

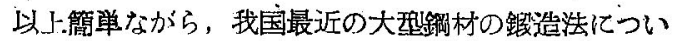


て述べたが，終戦以来，復興に明け暮れた 10 年の今日 多、の面で国際氷準に達する邀に到つた雅は，ともかく 進歩したと言える・しかし，率直に言つて，これは，発
達の初期の段階に渐く荎したにすぎず，日進月歩の現代

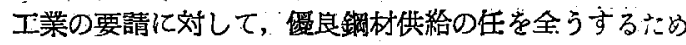
には，鍛造界は，更に向上の怒力を続けねばならない。

\section{本 邦 鑄 鉄, 鑄 龬 技術の進步}

\section{谷村 熙* \\ PROGRESS OF IRON AND STEEL CASTING INDUSTRY IN JAPAN

\author{
Hiromu Tanimura, Dr. Eng.
}

\section{Synopsis:}

A review of the iron and steel casting industry, during the past ten years, was described. The progress of the casting industry in this period has much correlation to the research activity in the pre-war and war time, therefore this review covers some details of pre-war progress.

\section{I. 第二次世界大戦前後にわたる 日本の鉡造界概況}

戦時には鋳物が陸上兵器, 艦船, 抗空機の主要部品に 用いられるので，その量産並びに筫の向上が要望せられ た・とれに関係する製造会社も研究に力をそそいだので 特物は备方面に進步を見た。特物の熏要性にかんがみ，

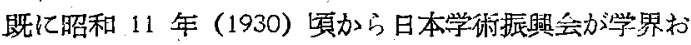
上び業界から委員を薷めて第. 24 小委員会を組織し特物 に関する総合畉究を推進した。るの委員㫳は不川登喜治 将士であつた。

戦時中は錆鋼が重視されるが，また各種機器に対し䤲 鉄，鉰合金，軽合金鋳物も重要な役目を担う。珠に航空 穖用にはアルミニウム，マグネシウム合金鋳物の需要が 多く，その呼究の促進と共に一般鋳造技術も進步した。

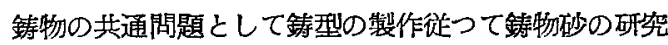
が必要となつてくる.よつて学振第 24 小委員会では鉦 物砂に関する專門部会を組織してその試験法の統一をは かつたままた兵器を初め主要な機器について多、の製造 会社の試作研究を集め鋳造作業標隻要を作つた。とれは 鋳鉄，鋳鋼，銅合金および軽合金の各材資にわたつて作 られ鋳造の指針となつた.

可龯鋳鉄は車轌，運搬機械等に用いられてきていた が，数社のメーカーは別としてとかく信賴性に乏しいと

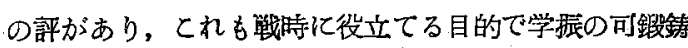
鉄専門部会で研究が取り上げられた。

次に防弾鋼は従来熱她理した特殊鋼鈑をりベット或い
は榕接を以て組立で来たが，リベットが弱点であり， また高張力の特殊鋼の熔接が困唯であるところから，特

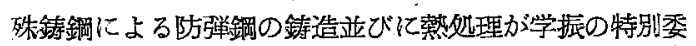
員会で取りあげられて研究の結果すぐれた鋳物が得られ た.

かように鋳物の各方面に関する技術が進んだが戦争末 期には資材の久乏と爆整による損害のために生库が裏无 て終戦を迎えた。

·敗戦直後は国家経济の混乱のため錆物業界も一時浓滞 したが，戦後の混乱がおさまり産業の復興が叫ばれると 拱に, 鋳物の需要も増加した. 然し乍ら原料の輸入注殆

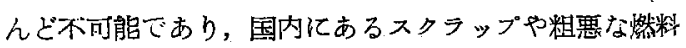
を用いて特物を作るととを余義なくされた.この時代に は粗恵恣材による鋳物の困嚾を克服する方法が研究さ れ，乙れがその後の錆物の品資改善にす往立つた. 1950 年顷から海外の情報が入り鉄鋼視察团のアメリカ視察宛 初め鉡物関係怵者の海外渡航もあり，欧来の鉡物の技 街を知り得たので急速なる改良進步が見られる様になつ た. 以下各種鋳物につき進歩の概略を述べることと斗 る.

\section{II. 鋳 鉄 鋳 物}

（1）戦㭙中の鋳鉄鋳物の研究

銬鉄は兵器や航空機の主要材料では無いかっら，戦時中 には目星しい進歩が見られたかつた・ただビストンリン

* 九州大学教授, 工学榑士 